\title{
Immunocapture-RT-PCR detection of Cassava common mosaic virus in cassava obtained from meristem-tip culture in Paraná state
}

\author{
Jaqueline M. Silva1 ${ }^{1}$, Patrícia R. Carnelossi' ${ }^{1}$, Taise Bijora ${ }^{1}$, Cassiele U. Facco ${ }^{1}$, Marcelo H.S. Picoli ${ }^{1}$, \\ Eliezer R. Souto ${ }^{1}$, Arildo J.B. Oliveira ${ }^{1}$ \& Álvaro M.R. Almeida ${ }^{2}$
}

${ }^{1}$ Departamento de Agronomia, Universidade Estadual de Maringá, 87020-900, Maringá, PR, Brazil; ${ }^{2}$ Embrapa Soja, 86001-970, Londrina, PR, Brazil

Author for correspondence: Eliezer R. Souto, e-mail: ersouto@uem.br

\begin{abstract}
A virus survey conducted in the northwest region of Paraná, the main cassava-producing region of that state, showed Cassava common mosaic virus (CsCMV) to be widespread, infecting more than $90 \%$ of plants from all cassava cultivars. A CsCMV isolate was purified and used to raise a high-titer (1/1.000) polyclonal antiserum for indexing plants produced from meristem-tip culture, using PTAELISA. From an initial production of 110 plants of cultivar Olho Junto, 31 remained infected as indicated by PTA-ELISA. To improve the sensitivity of virus detection, an immunocapture-RT-PCR (IC-RT-PCR) protocol was established. Virus-specific IgG, purified and combined with a primer set for the genus Potexvirus, could readily detect CsCMV in cassava crude leaf extracts. IC-RT-PCR products of $750 \mathrm{bp}$ were amplified from six out of 35 plants previously tested as virus-negative by PTA-ELISA. Sequence analysis of cloned IC-RTPCR products confirmed they were part of the CsCMV replicase gene, indicating that the virus was still present after thermotherapy and meristem-tip culture. PTA-ELISA enabled initial screening of virus-positive cassava, reducing the number of plants to be further analyzed by IC-RT-PCR. Though CsCMV has been considered of minor importance, its widespread nature, as noticed in Paraná, indicates the need for adoption of effective control measures.
\end{abstract}

Key words: Potexvirus, Euphorbiaceae, IC-RT-PCR, indexing, PTA-ELISA.

\section{RESUMO}

Deteç̧ão do Cassava common mosaic virus por immunocaptura-RT-PCR em mandioca obtida por cultura de meristemas no estado do Paraná

Em um levantamento conduzido na região noroeste do Paraná, principal região produtora de mandioca do estado, constatou-se que o CsCMV está amplamente disseminado, infectando mais de $90 \%$ das plantas de todas as cultivares. Um isolado do CsCMV foi purificado para a produção de um anti-soro policlonal de alto título (1/1000), o qual foi utilizado na indexação por meio de PTA-ELISA de plantas produzidas via cultura de meristemas. De uma produção inicial de 110 plantas da cultivar Olho Junto, 31 permaneceram infectadas como indicou o PTA-ELISA. Visando aumentar a sensibilidade de detecção do vírus, foi estabelecido um protocolo de IC-RT-PCR. A IgG purificada, específica para o vírus, combinada com um par de oligonucleotídeos universais para Potexvirus, prontamente detectou o CsCMV nos extratos obtidos de mandioca. Produtos de IC-RT-PCR de $750 \mathrm{pb}$ foram amplificados a partir de seis de um total de 35 plantas previamente testadas como negativas para o CsCMV via PTA-ELISA. Os sequenciamentos confirmaram que os produtos de IC-RT-PCR são parte do gene codificador da replicase do CsCMV, indicando assim a presença do vírus mesmo após a termoterapia combinada com a cultura de meristemas. O PTA-ELISA permitiu a triagem preliminar de plantas vírus-positivas, possibilitando a redução do número de plantas a serem analisadas por IC-RT-PCR. Embora o CsCMV seja considerado de importância menor, o fato desse vírus estar disseminado na região noroeste do Paraná recomenda a adoção de medidas efetivas para o seu controle.

Palavras-chave: Potexvirus, Euphorbiaceae, IC-RT-PCR, indexação, PTA-ELISA.

\section{INTRODUCTION}

Cassava root production for agro-industrial use is of great importance in the central and southern regions of Brazil. The state of Paraná currently accounts for $75 \%$ of Brazilian starch production, and the cassava industrial sector has created a continuous technological demand for improved quality of planting material (Abam, 2011). Cassava is vegetatively propagated and is prone to damage by viruses, as infection tends to build up after successive cycles of propagation. At least 16 viruses have been reported in the crop, among them Cassava common mosaic virus (CsCMV) (Calvert \& Tresh, 2002). CsCMV is a Potexvirus, and the virus particle is $15 \mathrm{~nm} \times 495 \mathrm{~nm}$ semiflexuous and rod-shaped (Kitajima et al., 1965). The viral genome consists of one ssRNA with 6376 nucleotides, and the coat protein is a single molecule of $21 \mathrm{kDa}$ (Nolt et al., 1991; Calvert et al., 1996). Cassava plants infected 
with CsCMV display mosaic symptoms and chlorotic areas that are often limited by the veins. The common mosaic disease caused by CsCMV was first described in cassava in Brazil by Silberschmidt (1938) and was considered of minor importance (Costa \& Kitajima, 1972). There are reports of CsCMV in other South American countries, as well as in Africa and Asia (Perera \& Dassanayake, 2002). Meristem-tip culture of cassava is an efficient method for obtaining virus-free propagative material. However, production of such healthy plants requires the use of highly specific, sensitive and rapid virus detection methods for plant indexing. Variations of ELISA are currently used for large-scale routine testing for viruses. Nevertheless, complementary PCR-based methods are desirable (Lunello et al., 2004). In this work, cassava plants grown from meristem-tip cultures indexed by PTA-ELISA were further tested to evaluate the efficiency of an IC-RT-PCR protocol for CsCMV detection in concentrations below the detection limit of ELISA.

\section{MATERIALS AND METHODS}

\section{Virus isolate and field survey}

Leaf samples of a symptomatic cassava plant, cultivar Baianinha, exhibiting systemic mild mosaic were tested to be positive for CsCMV by plate trapped antibody-ELISA (PTA-ELISA) with antiserum provided by Dr. Meissner Filho from Embrapa Mandioca e Fruticultura.

A polyclonal antiserum for CsCMV was raised and used to test 106 plants of cultivars Baianinha, IAC 90, IAC 12, Olho Junto and Fécula Branca collected in the northwestern cassava-producing area of Paraná.

\section{Virus purification and antiserum production}

Virus propagation was conducted in Nicotiana benthamiana by mechanical inoculation of crude sap using $0.02 \mathrm{M}$ potassium phosphate buffer, $\mathrm{pH}$ 7.0. CsCMV was purified according to Marys and Izaguirre-Mayoral (1995) with modifications. Systemically infected $N$. benthamiana leaves, harvested 30 days after inoculation, were ground in liquid nitrogen and homogenized in $0.1 \mathrm{M}$ potassium phosphate buffer, $\mathrm{pH} 7.6(1: 2 \mathrm{w} / \mathrm{v})$ containing $0.1 \%$ thioglycolic acid $\left(\mathrm{C}_{2} \mathrm{H}_{4} \mathrm{O}_{2} \mathrm{~S}\right)$ and $0.1 \mathrm{M}$ sodium diethyldithiocarbamate. After chloroform clarification and a low-speed centrifugation, the supernatant was stirred with 4\% PEG 6000 and centrifuged at $8000 \mathrm{~g}$ for $5 \mathrm{~min}$. The pellet was resuspended in $1 \mathrm{~mL}$ of $0.01 \mathrm{M}$ sodium phosphate buffer, $\mathrm{pH} 7.6$, layered over a sucrose gradient (10-40\%) and centrifuged at $110000 \mathrm{~g}$ for $60 \mathrm{~min}$. Fractions containing virus particles were collected and concentrated by highspeed centrifugation for $90 \mathrm{~min}$ at $34000 \mathrm{~g}$, and the final virus pellet was resuspended in sodium phosphate buffer. The molecular weight of the capsid protein was estimated by sodium dodecyl sulfate (SDS) - polyacrylamide gel electrophoresis on a $3.5 \%$ stacking gel and a $12 \%$ resolving gel. After electrophoresis for $2 \mathrm{~h}$ at $120 \mathrm{~V}$ at room temperature, proteins were stained with Coomassie brilliant blue (Figure 1). Antiserum was obtained by intramuscular injection into rabbits with a mixture of viral suspension and Freund's adjuvant $(1 \mathrm{mg} / \mathrm{mL})$. Injections were repeated twice at 10-day intervals, with incomplete Freund's adjuvant. Rabbits were bled starting one week after the last injection and the titers were evaluated by PTA-ELISA. Virus-specific IgG purification was performed according to McKinney \& Parkinson (1987).

\section{Thermotherapy and meristem-tip culture}

Plants without symptoms were chosen for meristem tip-culture. Cassava cuttings were sealed at their edges with paraffin wax and placed in a thermotherapy chamber for cultivation for 30 days under $16 \mathrm{~h}$ of light at $39^{\circ} \mathrm{C}$ followed by $8 \mathrm{~h}$ of dark at $28^{\circ} \mathrm{C}$. Buds of approximately $2-4 \mathrm{~cm}$ were removed and cultivated for 30 days in the same conditions. In vitro cultures were established in MS basic salt medium (Murashige \& Skoog, 1962) with 2\% sucrose and 0.6\% agar and supplemented with growth regulators. The cultures were maintained at $27^{\circ} \mathrm{C}$ with a cycle of $16 \mathrm{~h}$ light (photon flux of $22 \mu \mathrm{E} / \mathrm{m}^{2} / \mathrm{s}$ ) followed by $8 \mathrm{~h}$ dark.

\section{PTA-Elisa virus detection}

Young leaves were harvested from plants grown from meristem-tip culture after 12 months plus an additional 60 days in greenhouse acclimatization. Conditions for PTAELISA analysis were according to Mowat and Dawson

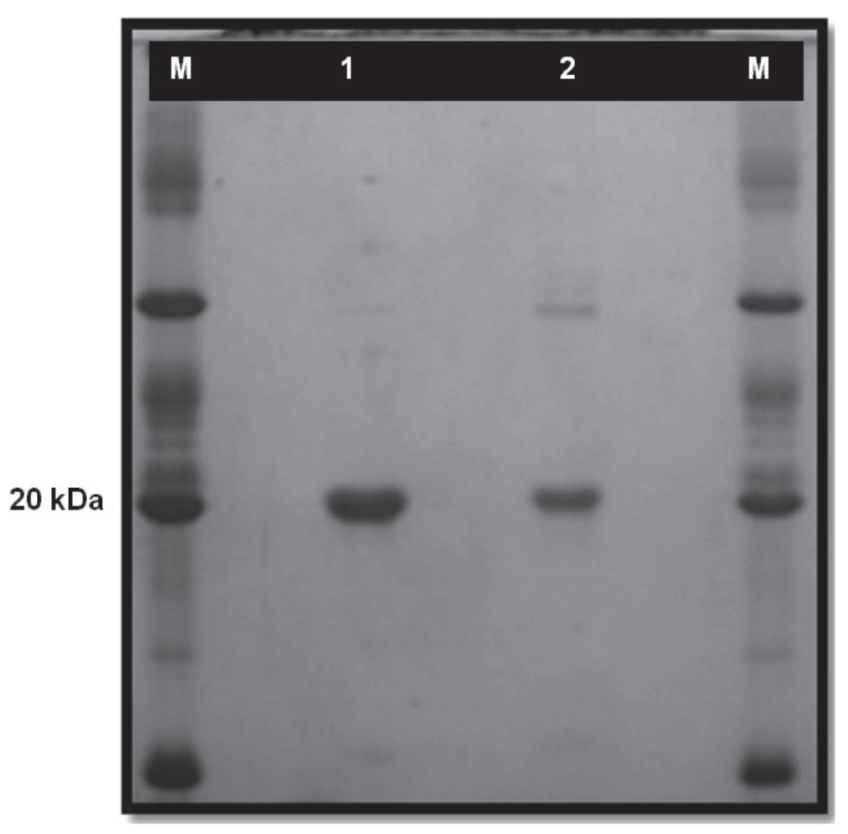

FIGURE 1 - Electrophoresis of CsCMV coat protein in a $15 \%$ SDS-polyacrylamide gel. Lanes 1 and 2 - Purified virus preparations after $10-40 \%$ sucrose gradient centrifugation; Lane M - marker proteins (10-160 kDa BenchMark Protein Ladder, Invitrogen). 
(1987). Each sample was tested in duplicate wells of a polystyrene microtiter plate. Extracts from healthy cassava cv. IAC 12 and Nicotiana benthamiana plants were used as negative controls. Extracts from an infected cassava cv. Baianinha and $N$. benthamiana plants were used as positive controls. Tests were considered positive when the absorbance $\left(\mathrm{A}_{405}\right)$ value of each sample was at least two times greater than that of the respective healthy control plant.

\section{IC-RT-PCR detection}

The primer set used in this work is universal for members of the genus Potexvirus (Potex1, 5'CAYCARCARGCXAARGAYSA-3'; Potex2, 5'-TCDGTR TTDGCRTCRAADGT-3') (Gibbs et al., 1998).

Immunocapture of CsCMV virions was performed in $0.2-\mathrm{mL}$ PCR tubes (Axygen) pre-coated with $50 \mu \mathrm{L}$ of virus-specific $\operatorname{IgG}(2 \mu \mathrm{g} / \mathrm{mL}$, in carbonate buffer $\mathrm{pH} 9.6)$, incubated for $180 \mathrm{~min}$ at $37^{\circ} \mathrm{C}$ and subsequently washed three times with PBS-Tween. Tubes were filled with 50 $\mu \mathrm{L}$ of extract $(0.1 \mathrm{~g}$ of leaf in $1 \mathrm{~mL}$ of PBS-Tween) and incubated at $6^{\circ} \mathrm{C}$ overnight, followed by two washes with PBS-Tween and one wash with DEPC-treated water prior to RT-PCR. Complementary DNA (cDNA) was prepared in a final volume of $20 \mu \mathrm{L}$. Tubes were filled with $1 \mu \mathrm{L}$ of random primers $(500 \mathrm{ng}), 2 \mu \mathrm{L}$ of dNTPmix $(10 \mathrm{mM})$ and $3 \mu \mathrm{L}$ of DEPC-treated water, heated at $65^{\circ} \mathrm{C}$ for $5 \mathrm{~min}$ and immediately chilled on ice. A misture of $4 \mu \mathrm{L}$ of $5 \mathrm{x}$ firststrand buffer $[250 \mathrm{mM}$ Tris- $\mathrm{HCl}(\mathrm{pH} 8.3), 375 \mathrm{mM} \mathrm{KCl}$, $\left.15 \mathrm{mM} \mathrm{MgCl}_{2}\right], 2 \mu \mathrm{L}$ of DTT $(0.1 \mathrm{M}), 1 \mu \mathrm{L}$ of RNAse OUT $(40 \mathrm{U})$ and $200 \mathrm{U}$ of M-MLV were added to the tubes. They were heated at $25^{\circ} \mathrm{C}$ for $10 \mathrm{~min}$ and then at $42^{\circ} \mathrm{C}$ for 50 min. For the PCR, $5 \mu \mathrm{L}$ of the cDNA was placed in a new tube, followed by $5 \mu \mathrm{L}$ of 10x PCR Buffer [ $200 \mathrm{mM}$ Tris$\mathrm{HCl}(\mathrm{pH} 8.4), 500 \mathrm{mM} \mathrm{KCl}], 3 \mu \mathrm{L}$ of $\mathrm{MgCl}_{2}(50 \mathrm{mM}), 2$ $\mu \mathrm{L}$ of dNTP mix $(10 \mathrm{mM}), 2 \mu \mathrm{L}$ of each primer $(10 \mu \mathrm{M})$, $1 \mu \mathrm{L}$ of Taq DNA polymerase ( $5 \mathrm{U}$ ) and $30 \mu \mathrm{L}$ of DEPCtreated water. The cycling profile consisted of an initial denaturing step at $94^{\circ} \mathrm{C}$ for $3 \mathrm{~min} ; 35$ cycles of $94^{\circ} \mathrm{C}$ for 3 $\min , 90 \mathrm{~s}$ at $51.5^{\circ} \mathrm{C}$ and $60 \mathrm{~s}$ at $72^{\circ} \mathrm{C}$; and a final extension step at $72^{\circ} \mathrm{C}$ for $10 \mathrm{~min}$. The amplification products were cloned into pGEM-T Easy vectors (Promega) and used to transform DH5a Escherichia coli competent cells according to the manufacturer's instructions. Recombinant plasmids were purified for nucleotide sequencing, and the sequences were compared with others from GenBank by the BLAST program of the National Center for Biotechnology Information (NCBI). IC-RT-PCR analysis was conducted in plants tested to be negative for CsCMV through PTAELISA.

\section{RESULTS AND DISCUSSION}

Ninety-six percent of the cassava samples reacted with the antiserum for CsCMV in PTA-ELISA tests. Though cassava common mosaic disease is considered to be of minor importance, this survey confirmed that CsCMV is widespread among all cultivated varieties of cassava in Paraná's northwestern producing area. The rate of virus infection ranged from $90-100 \%$ depending on the cultivar, and it was common to find virus infection in $100 \%$ of cultivar Baianinha plants (Table 1). Cassava vegetative propagation allows for virus accumulation in successive cycles. Therefore, it is of basic importance to produce healthy propagative material as a controlling measure.

Virus-free production of cassava was initiated by combining thermotherapy and meristem-tip culture for stock plant production of five cassava cultivars. The procedure was more efficient for cultivar Olho Junto and another variety from Thailand (data not shown). However, meristem-tip cultures were effective for virus elimination in most of the plants as shown by PTA-ELISA (Table 1). It has been reported that heat treatment hampers virus replication and enhances virus disorganization, thus leading to the eradication of the virus from shoot tips (Cooper \& Walkey, 1978). Recently, it was shown that viral RNA replication of Raspberry bushy dwarf virus (RBDV), a virus that enters meristematic tissues, was disorganized in leaves and shoot tips of plants growing at a high temperature $\left(38^{\circ} \mathrm{C}\right)$. This was attributed to the enhancement of RNA silencing, the cellular defense mechanism of plants that acts against viral RNA (Wang et al., 2008) and is significantly more active at higher temperatures (Chellappan et al., 2005).

The application of reliable and sensitive detection assays is also an important step in the process of plant

TABLE 1 - PTA-ELISA detection of CsCMV in cassava plants from the northwest region of Paraná State and in cassava grown from meristem-tip culture

\begin{tabular}{lcc}
\hline \hline Cassava cultivar & Infected / tested plants & \% of infected plants \\
\hline Olho Junto & $32 / 39$ & 90 \\
IAC 90 & $14 / 15$ & 93 \\
IAC 12 & $09 / 10$ & 90 \\
Fécula Branca & $19 / 20$ & 90 \\
Baianinha & $22 / 22$ & 100 \\
Total & $\mathbf{1 0 1 / 1 0 6}$ & $\mathbf{9 6}$ \\
Olho Junto from thermotherapy & $31 / 110$ & 28 \\
and meristem-tip culture & & \\
\hline
\end{tabular}


sanitation. This strategy involves the testing of plants produced by meristem-tip culture and routine testing of propagative material in the field. In principle, PTA-ELISA fulfils these requirements, as CsCMV was successfully eliminated from more than $70 \%$ of the Olho Junto plants. ELISA and its variations are routinely used for plant virus detection. However, it has been demonstrated that ELISA lacks the sensitivity required for very low-titer virus detection, as observed in plants from meristematic cultures. In an attempt to overcome this problem, RT-PCR has been widely used for detection of plant viruses (Dovas \& Katis, 2003).

In the present study, a primer set specific for the Potexvirus genus efficiently detected CsCMV. In order to circumvent plant preparation procedures and laborious nucleic acid extraction, an IC-RT-PCR procedure was adopted for detection of CsCMV in crude extracts of cassava leaves. Six samples that tested negative in PTA-ELISA tested positive in IC-RT-PCR (Figure 2). The comparison of 750-bp IC-RT-PCR product sequences with sequences from GenBank revealed a similarity of $87 \%$ with the replicase gene of a Brazilian isolate of Cassava common mosaic virus (GenBank accession no. U23414.1). According to the Eighth Report of the International Committee on Taxonomy of Viruses, Potexvirus species share more than $\sim 72 \%$ identical nucleotide sequences between their polymerase genes (Fauquet et al., 2005), confirming CsCMV infection of some plants even after thermotherapy followed by meristematic-tip culture. This result is in agreement with the sensitivity levels reported for other PCR-based methods

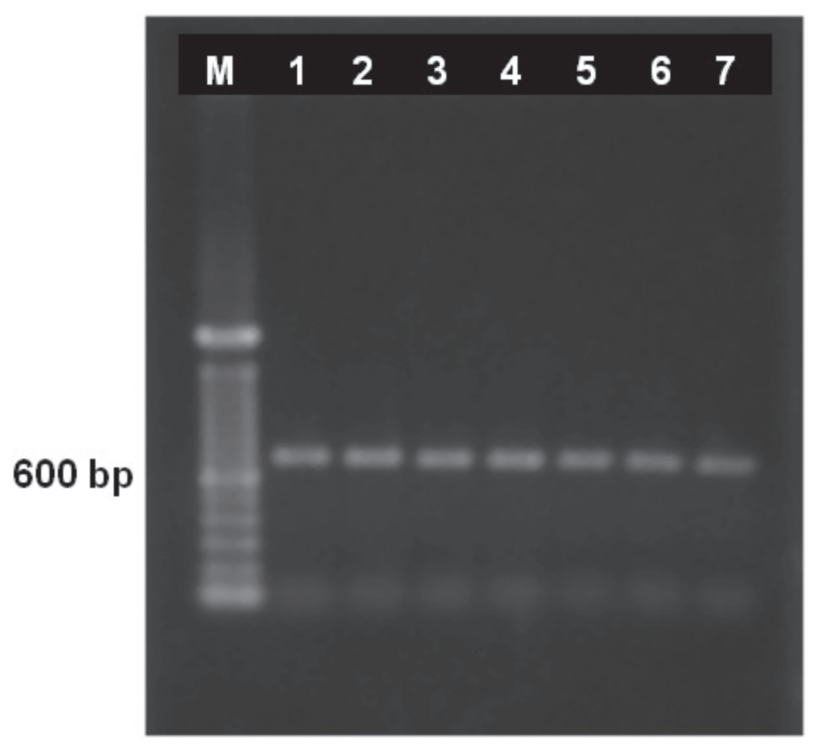

FIGURE 2 - Products of IC-RT-PCR, using Potexvirus universal primers, on RNA obtained from leaf extracts of cassava cultivar Olho Junto grown from meristem-tip culture combined with thermotherapy, which tested negative for CsCMV in PTA-ELISA. Lanes 1-6 - Samples of Olho Junto; Lane 7 - Infected cultivar Baianinha. M - 100 bp DNA Ladder. that proved more sensitive when the viral concentration was below the detection limit of ELISA (Dovas \& Katis, 2003).

The increased sensitivity obtained through molecular methods is indisputable, but the high cost of these tests and the small number of samples that can be screened at one time limits their widespread use. Therefore, PTA-ELISA is more convenient for an initial screening for plants with higher virus concentrations, and plants that test negative can be further assayed by IC-RT-PCR. Considering that cassava is an important crop in Paraná state, further investigations of the impact of common mosaic disease on cassava production, mainly in areas where CsCMV is widespread, are desirable. Introduction of virus-free cassava planting material will contribute to increased cassava production. As a rule, potexvirus species have no vector although they are easily transmitted by mechanical contact. Therefore, although a vector for CsCMV is currently not known, in the field, virus-free plants will probably suffer reinfection within some years of cultivation. It should therefore be convenient for growers to keep a stock of healthy plants for constant replacement with new virus-free material.

A previous survey to determine the presence of viruses affecting cassava in eight Brazilian states, including Paraná, found Cassava vein mosaic virus (CVMV, genus Cavemovirus) in the semi-arid region of the northeastern states of Ceará, Pernambuco and Bahia (Calvert et al., 1996). In the present survey, conducted in the northwest region of Paraná, no plants were found to display CVMVlike symptoms, such as vein chlorosis, leaf distortion or epinasty. The antiserum raised against CsCMV in this work will be valuable for future virus surveys in other producing areas of Paraná and for monitoring the progress of reinfection in the field of virus-free plants produced from meristem-tip culture. More sensitive systems, such as the IC-RT-PCR tested for CsCMV detection, may enable accurate virus detection even during warm periods of the growing season, when virus concentration is low.

The nucleotide sequence of CsCMV isolate from Paraná (CsCMV-PR) is deposited in the GenBank under the accession number JF913280.

\section{ACKNOWLEDGEMENTS}

This work was supported by FINEP/SEBRAE. We also thank Conselho Nacional de Desenvolvimento Científico e Tecnológico - CNPq and Coordenação de Aperfeiçoamento de Pessoal de Nível Superior - CAPES for fellowship assistance.

\section{REFERENCES}

ABAM - Associação Brasileira dos Produtores de Amido de Mandioca. Available in http://www.abam. com.br/prod_amido_ est_2007.php. Accessed on May 1 ${ }^{\text {st }}, 2011$. 
Calvert LA, Cuervo MI, Ospina MD, Fauquet CM (1996) Characterization of cassava common mosaic virus and a defective RNA species. Journal of General Virology 77:525-530.

Calvert LA, Thresh JM (2002) Virus and virus diseases of Cassava. In: Hillocks RJ, Thresh, JM, Belloti, AC (Eds.) Cassava Biology, Production and Utilization. CAB International Publishing, UK. pp. 237-260.

Chellappan P, Vanitharani R, Ogbe F, Fauquet CM (2005) Effect of temperature on geminivirus-induced RNA silencing in plants. Plant Physiology 138:1828-1841.

Cooper VC, Walkey DGA (1978) Thermal inactivation of cherry leaf roll virus in tissue cultures of Nicotiana rustica raised from seeds and meristem tips. Annals of Applied Biology 88:273-278.

Costa AS, Kitajima EW (1972) Cassava common mosaic virus. CMI/AAB Description of plant viruses n. 90 .

Dovas CI, Katis NI (2003) A spot nested RT-PCR method for the simultaneous detection of members of the Vitivirus and Foveavirus genera in grapevine. Journal of Virological Methods 107:99-106.

Fauquet CM, Mayo MA, Maniloff J. Desselberger U, Ball LA (Eds) (2005) Virus taxonomy. $8^{\text {th }}$ Report of the International Committee on Taxonomy of Viruses. Elsevier Academic Press. San Diego CA.

Gibbs A, Armstrong J, Mackenzie AM, Weiller GF (1998) The GPRIME package: computer programs for identifying the best regions of aligned genes to target in nucleic acid hybridizationbased diagnostic tests, and their use with plant viruses. Journal of Virological Methods 74:67-76.

Kitajima EW, Wetter C, Oliveira AR, Silva DM, Costa AS (1965) Morfologia do vírus do mosaico comum da mandioca. Bragantia 24:247-260.
Lunello P, Mansilla C, Conci V, Ponz P (2004) Ultrasensitive detection of two garlic potyviruses using a realtime fluorescent (Taqman) RT-PCR assay. Journal of Virological Methods 118:1521.

Marys E, Izaguire-Mayoral ML (1995) Isolation and characterization of a new Venezuelan strain of cassava common mosaic virus. Annals of Applied Biology 127:105-112.

McKinneyMM,ParkinsonA(1987)Asimple, non-chromatographic procedure to purify immunoglobulins from serum and ascites fluid. Journal of Immunological Methods 96:271-278.

Mowat WP, Dawson S (1987) Detection and identification of plant viruses by ELISA using crude sap extracts and unfractionated antisera. Journal of Virological Methods 15:233-247.

Murashige T, Skoog F (1962) A revised medium for rapid growth and bioassays with tobacco tissue cultures. Physiologia Plantarum $15: 473-497$.

Nolt BL, Velasco AC, Pineda B (1991) Improved purification procedure and some serological and physical properties of Cassava common mosaic virus from South America. Annals of Applied Biology 118:105-113.

Perera WGS, Dassanayake EM (2002) Identification and detection of Cassava mosaic virus in cassava. Annals of the Sri Lanka Department of Agriculture 4:313-318.

Silberschimit K (1938) O mosaico da mandioca. O Biológico 4:177-182.

Wang Q, Cuellar WJ, Rajamaki ML, Hirata Y, Valkonen JPT (2008) Combined thermotherapy and cryotherapy for efficient virus eradication: Relation of virus distribution, subcellular changes, cell survival and RNA degradation in shoot tips. Molecular Plant Pathology 9:237-250. 